\title{
Degeneration of chronic intertrigo into squamous cell carcinoma
}

\section{Mohamed El Amraoui, Rachid Frikh, Naoufal Hjira, Mohammed Boui}

\author{
Department of Dermatology-Venereology, Mohammed V Military Training Hospital, Rabat, Morocco \\ Corresponding author: Dr. Mohamed El Amraoui, E-mail: med.elamraoui.dto@gmail.com
}

Squamous cell carcinoma is the second carcinoma of the skin after basal cell carcinoma, which is known to have a poorer prognosis due to its lymphophilic character with frequent lymph node and visceral metastases [1,2]. Several precancerous lesions, genetic and acquired, are providers, including irritations and inflammatory chronic mucocutaneous conditions, as shown by the clinical case of a 65-year-old woman, diabetic on oral antidiabetics, with a history of recurrent mycotic intertrigo, who consulted for a swelling of the fourth and fifth toes evolving for more than 3 months and resistant to usual treatment. A dermatological examination found a tumefied, ulcerated, slightly necrotic and bleeding intertrigo in contact with the fifth right inter-toe space, and an onychodystrophy of a mycotic appearance (Figs. la and $1 b)$. Popliteal and inguinal lymph nodes were free. A histological study of a cutaneous biopsy favored moderately differentiated squamous cell carcinoma. A paraclinical extension assessment was reassuring. The patient was subsequently referred for plastic surgery. In conclusion, the prevention of this type of cancer involves the treatment and correct and early management of precancerous conditions, including chronic inflammatory conditions of the skin.

\section{Consent}

The examination of the patient was conducted according to the principles of the Declaration of Helsinki.

The authors certify that they have obtained all appropriate patient consent forms, in which the patients have given consent for images

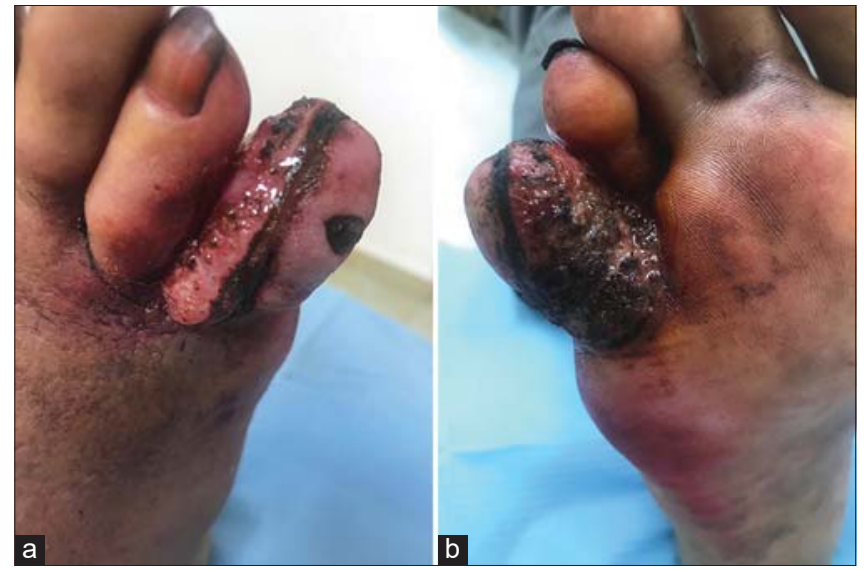

Figure 1: (a-b) An ulcer-budding tumor of the fifth right toe complicated by a chronic mycotic intertrigo.

and other clinical information to be included in the journal. The patients understand that their names and initials will not be published and due effort will be made to conceal their identity, but that anonymity cannot be guaranteed.

\section{REFERENCES}

1. Varma R, Asokan N, Sarin A, Rahman N. Unusually localised cutaneous multifocal squamous cell carcinoma. Our Dermatol Online. 2019;10:170-2.

2. Bartoš V. Cutaneous squamous cell carcinoma arising from the hair follicle. Our Dermatol Online. 2019;10:208-10.

Copyright by Mohamed El Amraoui, et al. This is an open access article distributed under the terms of the Creative Commons Attribution License, which permits unrestricted use, distribution, and reproduction in any

medium, provided the original author and source are credited.

Source of Support: Nil, Conflict of Interest: None declared.

How to cite this article: Mohamed El Amraoui, Rachid Frikh, Naoufal Hjira, Mohammed Boui. Degeneration of chronic intertrigo into squamous cell carcinoma. Our Dermatol Online. 2021;12(1):76.

Submission: 13.12.2019; Acceptance: 18.02 .2020

DOI: 10.7241 /ourd.20211.20 